\title{
THINNING OF THE ICE SHEET ESTIMATED FROM TOTAL GAS CONTENT OF ICE CORES IN MIZUHO PLATEAU, EAST ANTARCTICA
}

\author{
by \\ Takao Kameda \\ (Institute of Low Temperature Science, Hokkaido University, Sapporo 060, Japan) \\ Masayoshi Nakawo \\ (Nagaoka Institute of Snow and Ice Studies, National Research Center for Disaster Prevention, STA, \\ Nagaoka 940, Japan) \\ Shinji Mae
}

(Department of Applied Physics, Faculty of Engineering, Hokkaido University, Sapporo 060, Japan)

Okitsugu Watanabe

(National Institute of Polar Research, 9-10, Kaga 1-chome, Itabashi-ku, Tokyo 173, Japan)

and

Renji Naruse

(Institute of Low Temperature Science, Hokkaido University, Sapporo 060, Japan)

\section{ABSTRACT}

A linear relation between total gas content in ice and the elevation of ice formation (i.e. pore close-off) was obtained from seven shallow ice cores in Mizuho Plateau, Antarctica. The derived relation was applied to the vertical profile of total gas content in a $700 \mathrm{~m}$ long ice core at Mizuho Station. A general trend of gradual increase in total gas content was observed from 600 to $200 \mathrm{~m}$ in depth, from which toward the upper layer it showed a steep increase. After eliminating the effect of down-slope flow of ice around Mizuho Station, it was estimated that the thickness of the ice sheet decreased by about $350 \mathrm{~m}$ at maximum during the last 2000 years. This tendency also appears in the $\delta^{18} \mathrm{O}$ profile of the same ice core.

\section{INTRODUCTION}

Air bubbles in polar glacier ice are formed by the densification process of firn into ice. Composition of air in ice is essentially the same as that of the atmosphere at the time of bubble formations; thus the analyses of air in ice allow us to investigate the past atmospheric conditions (Scholander and others, 1961; Matsuo and Miyake, 1966; Stauffer and Berner, 1978; Oeschger and others, 1982; Barnola and others, 1987; Etheridge and others, 1988).

Total gas content is defined as a volume of air involved in unit mass of ice measured under conditions of standard temperature and pressure $\left(0^{\circ} \mathrm{C}\right.$ and 1 atmosphere). Knowing the temperature at a point where the air is trapped within the ice, we can estimate the air pressure at the point from total gas content in ice. Hence, the total gas content is considered as an indicator of elevation at bubble formation (i.e. elevation at pore close-off), as stated by Lorius and others (1968). Raynaud and Lebel (1979) primarily presented an empirical relation between the total gas content and the elevation of sampling site by using ice cores drilled at different altitudes in the Antarctic and Greenland ice sheets. This relationship has been applied to estimate past ice-sheet elevation (Raynaud and Whillans, 1982; Jenssen and Radok, 1982; Herron and Langway,
The ice-core drilling project in Mizuho Plateau, Antarctica, has been carried out by the Japanese Antarctic Research Expeditions (JARE) since 1971. More than ten shallow ice cores were recovered in this area, and the JARE-25 accomplished the drilling of an ice core to a depth of $700.56 \mathrm{~m}$ at Mizuho Station in August 1984.

The present paper gives an empirical relation between total gas content and the elevation at pore close-off using shallow ice cores from Mizuho Plateau. The derived relation was applied to the vertical profile of total gas content in a $700 \mathrm{~m}$ deep ice core of Mizuho Station to estimate a past elevation of the ice sheet around the area.

\section{EXPERIMENTAL PROCEDURE}

Total gas contents were measured by both "melting method" and "dry extraction method". The procedure of melting method was described in detail by Langway (1958). The outline of this method is: air in an ice sample is extracted by melting the sample in a liquid and is introduced into a gas burette; then the total volume of air, and temperature and atmospheric pressure, are measured. This method is easy to perform, and is suited for relatively large samples from 20 to $200 \mathrm{~g}$.

As a liquid, we employed a water- and air-saturated dimethyl silicon oil $\left(1.5 \times 10^{-6} \mathrm{~m}^{2} \mathrm{~s}^{-1}\right)$, not conventionallyused kerosene, because of its low vapour pressure, slight solubility for water and pure composition. We also measured the dissolved-air volume in the melt water. This procedure enables us to reduce the experimental error to about $1 \%$ for $80 \mathrm{~g}$ ice samples (Kameda and others, 1989).

The dry extraction method procedure was described in detail by Kameda and others (1989) in detail. The outline of this is: air in an ice sample is extracted by crushing the sample in a vacuum vessel, then the pressure and the temperature of released air are measured. Corrections were made for the amount of vapour pressure in air and also for the loss of air due to cutting air bubbles on the sample surface. The whole procedure was carried out in a cold room (about $-20^{\circ} \mathrm{C}$ ). For small samples (namely less than $20 \mathrm{~g}$ ), this method is more accurate than the melting method. Since there existed numerous fine cracks at 


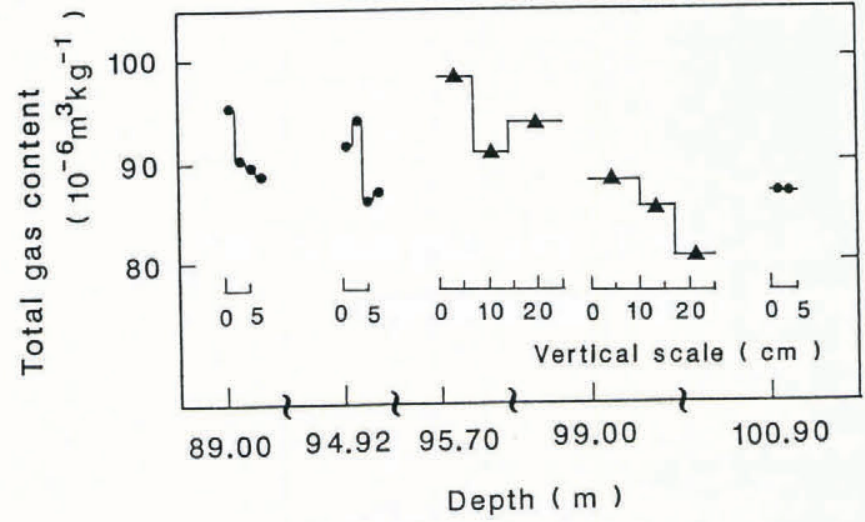

Fig. 1. Results of total gas contents from ice core from station G15 measured by melting method (triangles) and dry extraction method (solid circles).

intervals of $10 \mathrm{~mm}$ or less in the $700 \mathrm{~m}$ deep core of Mizuho Station (Mizuho core), only small pieces of ice samples of about 5 to $10 \mathrm{~mm}$ thick could be obtained below $120 \mathrm{~m}$ in depth and were subjected to measurements with the dry extraction method. Overall error for this method was estimated as less than 1\% (Kameda and others, 1989).

To examine systematic differences between the results by melting method and dry extraction method, total gas contents of ice core from station G15 were measured in detail from 89 to $100.9 \mathrm{~m}$ in depth, and are shown in Figure 1. Although obtained data scattered considerably, mainly due to the seasonal and year-to-year variations in total gas content, mean values of total gas contents by these two methods are $89.9 \times 10^{-6} \mathrm{~m}^{3} \mathrm{~kg}^{-1}$ and $89.6 \times 10^{-6}$ $\mathrm{m}^{3} \mathrm{~kg}^{-1}$, respectively. The difference between these was within the error of the two methods. Consequently it may within the error of the two methods. Consequently between these two procedures, and a mean value of several samples should be used at each station.

\section{RELATION BETWEEN TOTAL GAS CONTENT AND ELEVATION AT PORE CLOSE-OFF IN MIZUHO PLATEAU}

Total gas contents were measured for seven shallow ice cores from different altitudes in Mizuho Plateau, East Antarctica. A map showing the drilling sites is given in Figure 2; locations, surface elevations (Nakawo and others, 1984; Nishio, 1984; Ageta and others, 1987) and mean annual air temperatures estimated from $10 \mathrm{~m}$ snow temperatures are listed in Table I.

Total volume of air bubbles within a unit mass of core sample was measured from the depth of 50 to $90 \mathrm{~m}$ at station G15. The variation in bubble volumes with the bulk density of firn or ice is shown in Figure 3. It is clearly seen that the bubble volume increases gradually with increase in density from 720 to about $830 \mathrm{~kg} \mathrm{~m}^{-3}$ from

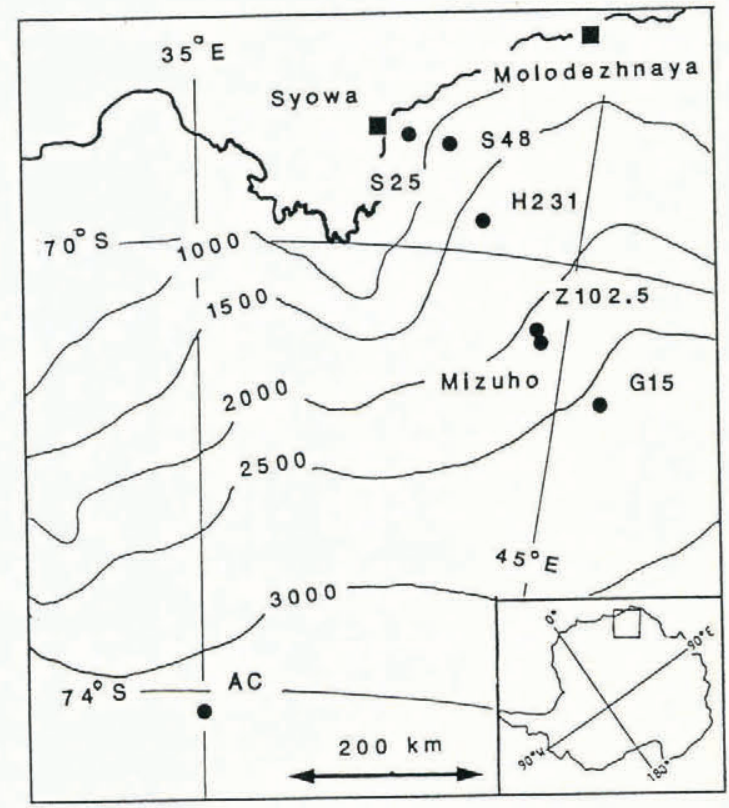

Fig. 2. Locations of ice coring sites in Mizuho Plateau, East Antarctica.

which it then decreases with density. The former increasing tendency is considered to result from increase in the number of air bubbles which had closed off, while the latter is caused by the compaction of air bubbles in ice. Hence, we regard the density of $830 \mathrm{~kg} \mathrm{~m}^{-3}$, where the volume of air bubbles indicated a maximum value, as the bulk density at pore close-off, and we assume it holds all over the Mizuho Plateau area. Elevation at pore close-off in each site was then determined by subtracting, from the surface elevation, the depth of the critical density estimated from a density profile of firn and ice, also shown in Table I. All these ice cores were recovered from 1979 to 1986.

To establish a relation between total gas content and elevation at pore close-off, samples subjected to measurements were those from 20 to $50 \mathrm{~m}$ below the transition from firn to ice. Such ice cores contained almost spherical air bubbles, which favoured corrections for air loss due to cutting the sample surface (Nakawo and Narita, 1985), and were also considered to be at almost the same temperature and pressure as those at the level of pore close-off. The numbers of measurements of total gas content for each site were between two at station S48 and 16 at station G15, as shown in Table I. At each site except S48, total gas contents were measured continuously along more than $0.25 \mathrm{~m}$ of ice core, which is equivalent to snow accumulation of $1-3$ years.

Mean value of total gas content $R\left(\mathrm{~m}^{3} \mathrm{~kg}^{-1}\right)$ obtained for each site is shown in Table $I$, and plotted against the elevation at pore close-off $E(\mathrm{~m})$ in Figure 4 . Values of $R$ show a tendency to decrease almost linearly with $E$, except

TABLE I. LOCATIONS AND ELEVATIONS OF DRILLING SITES, AND MEAN TOTAL GAS CONTENTS IN ICE CORES

\begin{tabular}{|c|c|c|c|c|c|c|}
\hline \multirow[t]{2}{*}{$\begin{array}{l}\text { Drilling } \\
\text { site }\end{array}$} & $\begin{array}{l}\text { Latitude } \\
\text { and } \\
\text { longitude }\end{array}$ & $\begin{array}{l}\text { Surface } \\
\text { elevation }\end{array}$ & $\begin{array}{l}\text { Elevation } \\
\text { at pore } \\
\text { close-off }\end{array}$ & $\begin{array}{l}\text { Mean } \\
\text { annual air } \\
\text { temperature }\end{array}$ & $\begin{array}{l}\text { Mean total } \\
\text { gas content }\end{array}$ & $\begin{array}{c}\text { Number } \\
\text { of } \\
\text { samples }\end{array}$ \\
\hline & & $\mathrm{m}$ & $\mathrm{m}$ & ${ }^{\circ} \mathrm{C}$ & $10^{-6} \mathrm{~m}^{3} \mathrm{~kg}^{-1}$ & \\
\hline $\begin{array}{l}\text { S25 } \\
\text { S48 }\end{array}$ & $69^{\circ} 02^{\prime} \mathrm{S}, 40^{\circ} 31^{\prime} \mathrm{E}$ & 868 & 818 & -17.96 & 116.5 & 7 \\
\hline $\begin{array}{l}\text { S48 } \\
\text { H231 }\end{array}$ & $69^{\circ} 08^{\prime} \mathrm{S}, 41^{\circ} 17^{\prime} \mathrm{E}$ & 1223 & 1180 & -19 & 117.3 & 2 \\
\hline $\mathrm{H} 231$ & $69^{\circ} 46^{\prime} \mathrm{S}, 42^{\circ} 28^{\prime} \mathrm{E}$ & 1667 & 1607 & -25 & 112.1 & 6 \\
\hline $\mathrm{Z} 102.5$ & $70^{\circ} 41^{\prime} \mathrm{S}, 44^{\circ} 18^{\prime} \mathrm{E}$ & 2212 & 2157 & -32 & 95.8 & 5 \\
\hline $\begin{array}{l}\text { Mizuho } \\
\text { Station }\end{array}$ & $70^{\circ} 42^{\prime} \mathrm{S}, \quad 44^{\circ} 20^{\prime} \mathrm{E}$ & 2260 & 2205 & -33.55 & 98.9 & 13 \\
\hline G15 & $71^{\circ} 12^{\prime} \mathrm{S}, 45^{\circ} 59^{\prime} \mathrm{E}$ & 2571 & 2496 & -37.8 & 89.7 & 16 \\
\hline Advance & $74^{\circ} 12^{\prime} \mathrm{S}, 34^{\circ} 59^{\prime} \mathrm{E}$ & 3190 & 3110 & -44.5 & 78.4 & 13 \\
\hline
\end{tabular}



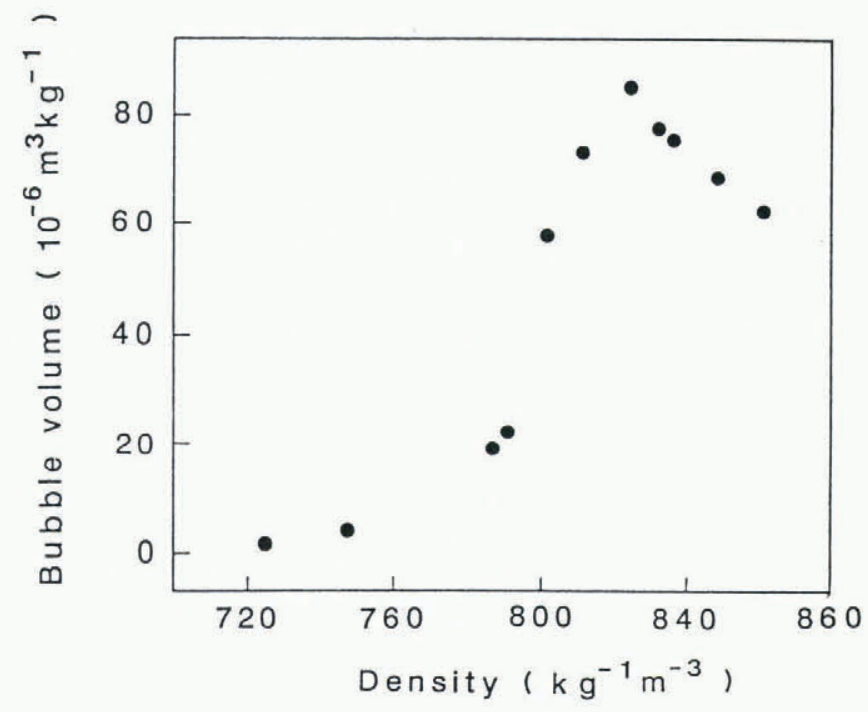

Fig. 3. Total volume of air bubbles in a unit mass of firn or ice core versus the bulk density at station G15.

for the data of S25 where elevation is lowest among the seven stations. Site S25 is characterized by relatively high accumulation rate, i.e. about $0.25 \mathrm{~m} \mathrm{a}^{-1}$ in water equivalent, and high temperature, i.e. $-17.96^{\circ} \mathrm{C}$ at $10 \mathrm{~m}$ in depth (personal communication from K. Satow), compared with other sites Mizuho Plateau. These regional characteristics of depositional regime should cause changes in the densification process of firn, so that the density at pore close-off in S25 may differ from that in inland areas. Hence, excluding the point of S25, the following empirical relation was obtained from 55 observations of total gas contents in Mizuho Plateau:

$$
R=\left(-2.17 \times 10^{-8} E\right)+\left(145 \times 10^{-6}\right) .
$$

The result of Raynaud and Lebel (1979) is also shown with open squares and a broken line in Figure 4. The difference between these two lines is considered due to the difference in climate of the regions; accumulation rate may be the key factor to it.

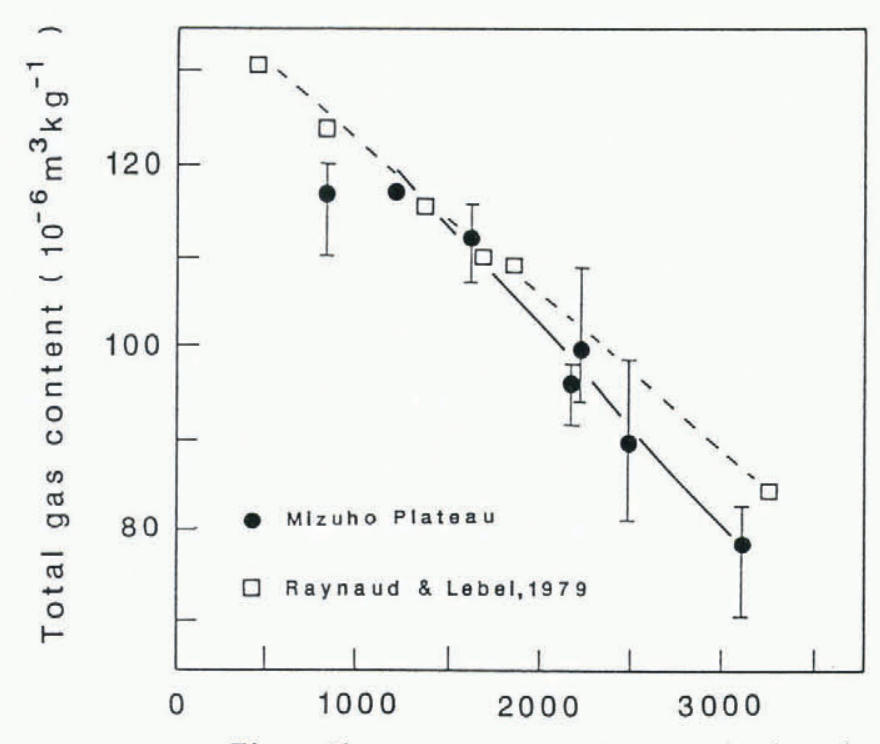

Fig. 4. Mean total gas content in ice core from 20 to $50 \mathrm{~m}$ below the firn-ice transition versus the elevation (a.s.l.) at pore close-off in Mizuho Plateau. Maximum and minimum values of total gas content are indicated by bars. Open squares and a broken line are the results of Raynaud and Lebel (1979), in which Antarctic and Greenland ice cores are used.

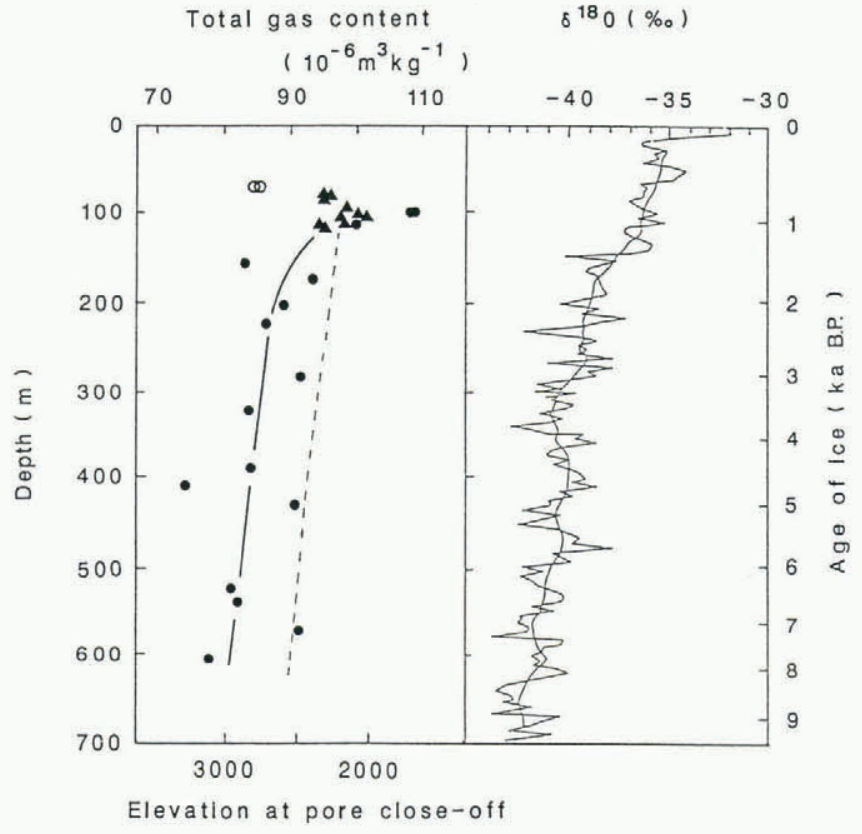

$(\mathrm{m})$

Fig. 5. Vertical profile of total gas content and $\delta^{18} \mathrm{O}$ (Higashi and others, 1988) in the $700 \mathrm{~m}$ deep ice core at Mizuho Station. A solid line of total gas content is fitted to the measured data (solid circles and triangles). The broken line indicates the profile of original elevation at which pore close-off took place, calculated under a steady-state assumption. Along the lower abiscissa the estimated elevation at pore close-off is shown.

\section{PAST ICE-SHEET ELEVATION AROUND MIZUHO STATION}

The vertical profile of total gas content plotted against depth at Mizuho Station is shown in the left column of Figure 5 and Table II. Circles and triangles indicate values measured by dry extraction method and melting method, respectively. The two open circles in a shallow layer are only for reference, since the air bubbles were not spherical and corrections for surface effect were insufficient.

Values of total gas content scattered considerably. The width of scattering is about $10 \times 10^{-6} \mathrm{~m}^{3} \mathrm{~kg}^{-1}$ at maximum, which is almost the same as a seasonal variation in total gas content reported in Raynaud and Lebel (1979). As for a general trend of change in total gas content $R$, we can see a gradual increase in $R$ from 600 to about $200 \mathrm{~m}$ in depth, followed by a steep increase toward the upper layer. By using a least squares regression method, a straight line was fitted to the data in the deep layer and a curve to the data in the shallow layer as shown in Figure 5.

The original elevation at which the deep ice of the Mizuho core was transformed from firn, that is the elevation at pore close-off, was estimated assuming that the relation in Equation (1) was valid for the past period. The elevations are shown on the lower abscissa in Figure 5 . It is clear that the deeper ice should indicate the lower value of total gas content since the deeper one has originated at higher elevation of the ice sheet. To discuss the causes for gradual then sudden change in total gas contents, one has to evaluate the effect of down-slope movement of ice.

Calculations of particle path lines from points on the ice-sheet surface to the corresponding depths in the Mizuho core were made by using a three-dimensional steady-state flow model (Takahashi and Nakawo, 1982). Major input data for calculation are the topography of top and bottom surfaces of the ice sheet (Nakawo and others, 1984), the width between adjacent flow lines (Naruse and Shimizu, 1978), and the surface mass balance (Nakawo and others, $1984)$ in the up stream area of Mizuho Station. Estimated original elevations at which pores would have closed off under the present flow regime are shown by a broken line in Figure 5 for various depths in the Mizuho core. Also 
TABLE II. NUMERICAL VALUES OF TOTAL GAS CONTENT OF MIZUHO $700 \mathrm{~m}$ ICE CORE

$\begin{array}{ccc}\text { Core no. Depth } & \text { Total gas content } \\ \mathrm{m} & 10^{-6} \mathrm{~m}^{3} \mathrm{~kg}^{-1}\end{array} \quad$ Method

\begin{tabular}{|c|c|c|c|}
\hline M-179 & $70.00-70.01$ & 86.0 & dry extraction \\
\hline M-179 & $70.08-70.09$ & 85.1 & dry extraction \\
\hline$M-274$ & $100.10-100.11$ & 109.3 & dry extraction \\
\hline$M-274$ & $100.15-100.16$ & 108.6 & dry extraction \\
\hline M-309 & $110.02-110.03$ & 99.8 & dry extraction \\
\hline$M-422$ & $158.47-158.48$ & 83.0 & dry extraction \\
\hline M-447 & $170.33-170.34$ & 93.4 & dry extraction \\
\hline$M-512$ & $202.72-202.73$ & 89.2 & dry extraction \\
\hline$M-555$ & $223.87-223.88$ & 86.6 & dry extraction \\
\hline M-679 & $282.95-282.96$ & 91.4 & dry extraction \\
\hline M-767 & $324.46-324.47$ & 81.9 & dry extraction \\
\hline M-911 & $391.58-391.59$ & 83.6 & dry extraction \\
\hline$M^{\prime}-572$ & $409.69-409.70$ & 74.0 & dry extraction \\
\hline$M^{\prime}-613$ & $429.97-929.98$ & 90.5 & dry extraction \\
\hline$M^{\prime}-796$ & $519.83-519.84$ & 81.3 & dry extraction \\
\hline$M^{\prime}-826$ & $534.60-534.61$ & 83.5 & dry extraction \\
\hline$M^{\prime}-893$ & $567.06-567.07$ & 91.3 & dry extraction \\
\hline$M^{\prime}-964$ & $601.90-601.91$ & 78.0 & dry extraction \\
\hline M-212 & $80.10-80.18$ & 95.0 & melting \\
\hline$M-212$ & $80.18-80.27$ & 94.2 & melting \\
\hline M-212 & $80.38-80.47$ & 93.0 & melting \\
\hline$M-241$ & $90.12-90.19$ & 98.6 & melting \\
\hline$M-274$ & $100.20-100.26$ & 100.7 & melting \\
\hline$M-274$ & $100.26-100.32$ & 97.6 & melting \\
\hline$M-274$ & $100.32-100.41$ & 98.1 & melting \\
\hline$M-274$ & $100.41-100.44$ & 101.8 & melting \\
\hline M-309 & $110.07-110.19$ & 94.3 & melting \\
\hline M-309 & $110.07-110.16$ & 95.2 & melting \\
\hline
\end{tabular}

shown on the right ordinate of Figure 5 is an estimated time scale of ice in the Mizuho core determined by Nakawo and others (1989). Usually the age of air in bubbles is different from that of surrounding ice due to air mixing in the firn layer (Schwander and others, 1988). For the Mizuho core, however, we may regard the time scale of ice as that of the air in the bubbles, because little mixing may have occurred due to the existence of ice crusts, including multi-layered ice crusts, as shown in the vertical profile of stratigraphy in the Mizuho core (Narita and others, 1978).

In Figure 5, the solid line is smaller than the broken one in the layer deeper than $200 \mathrm{~m}$, by $7.8 \times 10^{-6} \mathrm{~m}^{3} \mathrm{~kg}^{-1}$. These values are equivalent to about $350 \mathrm{~m}$ in elevation difference, from Equation (1).

Values of total gas contents below $120 \mathrm{~m}$ in depth, however, might be smaller than the original values due to the gas release through micro-cracks which cannot be detected in sample preparations, since these samples were selected between visible cracks in the ice core. Hence the difference of about $350 \mathrm{~m}$ as shown in Figure 5 may be a maximum value which can be estimated from the result of total gas content profile.

Consequently, if we assume that the present relationship of air temperature and pressure with elevation would be valid through the last few thousand years, thickness of the ice sheet decreased by about $350 \mathrm{~m}$ at maximum from about 2000 years B.P.

In order to compare the results of total gas content with that of $\delta^{18} \mathrm{O}$, the vertical profile of $\delta^{18} \mathrm{O}$ along the same ice core (Higashi and others, 1989) is shown in the right column of Figure 5. A thin zig-zag line represents every $5 \mathrm{~m}$ value and a solid line shows the running mean over ten successive values.

The general trend of increase in $8^{18} \mathrm{O}$ with decrease in depth from 700 to about $200 \mathrm{~m}$ is due mostly to the down-slope movement of ice from the high land. However, the remarkable increase in $\delta^{18} \mathrm{O}$ (about 2.8\%) is recognized from 200 to $100 \mathrm{~m}$ in depths, where total gas content data shows also sudden increase. To discuss the cause of this remarkable increase of $\delta^{18} \mathrm{O}$, we have to evaluate the effect of down-slope movement of ice as the same way of total gas content analyses.
From calculations of particle path lines described previously, it was estimated that the original elevation of $200 \mathrm{~m}$-deep ice was about $70 \mathrm{~m}$ higher than that of $100 \mathrm{~m}$ deep ice. Using the gradient of $\delta^{18} \mathrm{O}$ of deposited snow against $10 \mathrm{~m}$ snow temperature, $0.91 \% 0 /{ }^{\circ} \mathrm{C}$ (by personal communication from Y. Fujii), and the mean lapse rate of $10 \mathrm{~m}$ snow temperature in Mizuho Plateau $\left(-1.25^{\circ} \mathrm{C} / 100 \mathrm{~m}\right)$ derived by Satow and Kikuchi (1989), it was estimated that the difference of $70 \mathrm{~m}$ in surface elevation results in a difference of $0.8 \%$ in $\delta^{18} \mathrm{O}$ between 200 and $100 \mathrm{~m}$-deep ice.

On the other hand, to estimate a relative warming at Mizuho Station caused by $350 \mathrm{~m}$ thinning of the ice sheet, an aerological temperature gradient above the inversion layer at Mizuho Station $\left(-0.5^{\circ} \mathrm{C} / 100 \mathrm{~m}\right.$; figure $3.8(\mathrm{a})$ in National Institute of Polar Research, 1988) can be used. It is, therefore, estimated that the $350 \mathrm{~m}$ decrease in ice-sheet elevation may caused by a relative warming about $1.8^{\circ} \mathrm{C}$ of mean annual temperature. This values also corresponds with an increase of about $1.6 \%$ in $\delta^{18} \mathrm{O}$.

Consequently, most of the increase in $\delta^{18} \mathrm{O}$ from 200 to $100 \mathrm{~m}(2.8 \% 0)$ was explained by relative warming due to thinning of the ice sheet $(1.6 \%)$, and by the down-slope movement of the ice $(0.8 \%)$ ). The remainder (about $0.4 \%$ ) of $\delta^{18} \mathrm{O}$ may correspond to climatic warming around Mizuho Station. However, the contribution of this climatic warming (about $0.5^{\circ} \mathrm{C}$ ) may be slightly underestimated since $350 \mathrm{~m}$ thinning of the ice sheet is possibly an overestimate, for reason described previously.

\section{CONCLUDING REMARKS}

The vertical profile of total gas content of the Mizuho $700 \mathrm{~m}$ ice core showed a sudden increase from 200 to $100 \mathrm{~m}$ in depth. On the basis of a relation between total gas content and elevation at pore close-off derived at Mizuho Plateau, and also of the ice-sheet flow calculations under steady-state assumptions, this increase was explained by a $350 \mathrm{~m}$ decrease of the ice-sheet elevation at maximum from 2000 years B.P. The thinning tendency was recognized also in the $\delta^{18} \mathrm{O}$ profile of the same ice core from 200 to $100 \mathrm{~m}$ in depth. It was found that this increase in $8^{18} \mathrm{O}$ was mainly attributed to a relative warming caused by the $350 \mathrm{~m}$ decrease in the ice-sheet elevation.

The result of a thinning ice sheet from 2000 years B.P. may confirm that the thinning phenomenon, by a rate from $0.5 \mathrm{~m} \mathrm{a}^{-1}$ to about $1 \mathrm{~m} \mathrm{a}^{-1}$, directly measured with a short time interval in Mizuho Plateau (Naruse, 1979; Nishio and others, 1989), would be a long term trend of ice-sheet variation.

Although these considerations may be somewhat speculative at this stage, the results given in this paper should provide an insight to ice-sheet variations, until further analyses have been carried out.

\section{ACKNOWLEDGEMENTS}

This work is a contribution from the Glaciological Research Program in east Dronning Maud Land, Antarctica. We thank the members of JARE-20,21, 24, 25 and 26 , in particular those who made enormous efforts to recover ice cores. We are indebted also to Professor A. Higashi of International Christian University for his generous supervision of the Glaciological Research Program and to Dr Y. Fujii of the National Institute of Polar Research for discussion about $\delta^{18} \mathrm{O}$ data in Mizuho Plateau.

\section{REFERENCES}

Ageta, Y., T. Kikuchi, K. Kamiyama, and F. Okuhira. 1987. Glaciological research program in east Queen Maud Land, East Antarctica. Part 5, 1985. Tokyo, National Institute of Polar Research. (JARE Data Reports 125 (Glaciology 14).)

Barnola, J.M., D. Raynaud, Y.S. Korotkevich, and C. Lorius. 1987. Vostok ice core provides 160,000-year record of atmospheric $\mathrm{CO}_{2}$. Nature, 329(6138), 408-414.

Etheridge, D.M., G.I. Pearman, and F. de Silva. 1988. 
Atmospheric trace-gas variations as revealed by air trapped in an ice core from Law Dome, Antarctica. Ann. Glaciol., 10, 28-33.

Herron, S.L. and C.C. Langway, jr. 1987. Derivation of paleoelevations from total air content of two deep Greenland ice cores. International Association of Hydrological Sciences Publication 170 (Symposium at Vancouver 1987 - The Physical Basis of Ice Sheet Modelling), 283-295.

Higashi, A., M. Nakawo, H. Narita, Y. Fujii, F. Nishio, and O. Watanabe. 1988. Preliminary results of analyses of $700 \mathrm{~m}$ ice cores retrieved at Mizuho Station, Antarctica. Ann. Glaciol., 10, 52-56.

Jenssen, D. and U. Radok. 1982. On the joint interpretation of total gas contents and stable isotope ratios in ice cores. Ann. Glaciol., 3, 152-155.

Kameda, T., M. Nakawo, M. Nagoshi, and S. Mae. In press. Measurements of total gas content of an ice core from Mizuho Station, Antarctica. Proceedings of the NIPR Symposium on Polar Meteorology and Glaciology 3.

Langway, C.C., jr. 1958. Bubble pressures in Greenland glacier ice. International Association of Scientific Hydrology Publication 47 (Symposium at Chamonix 1958 Physics of the Movement of the Ice), 336-349.

Lorius, C., D. Raynaud, and L. Dolle. 1968. Densité de la glace et étude des gaz en profondeur dans un glacier antarctique. Tellus, 20(3), 449-460.

Matsuo, S. and Y. Miyake. 1966. Gas composition in ice samples from Antarctica. J. Geophys. Res., 71(22), 5235-5241.

Nakawo, M. and H. Narita. 1985. Density profile of a $413.5 \mathrm{~m}$ deep fresh core recovered at Mizuho Station, East Antarctica. Mem. Natl. Inst. Polar Res. Spec. Issue 39, 141-156.

Nakawo, M., H. Narita, and T. Isobe. 1984. Glaciological research program in east Queen Maud Land, East Antarctica. Part 2, 1983. Tokyo, National Institute of Polar Research. (JARE Data Reports 96 (Glaciology 11).)

Nakawo, M., H. Ohmae, F. Nishio, and T. Kameda. 1989. Dating the Mizuho $700-\mathrm{m}$ core from core ice fabric data. Proceedings of the NIPR Symposium on Polar Meteorology and Glaciology 2, 105-110.

Narita, H., O. Watanabe, K. Satow, and F. Okuhira. 1978. Compiled stratigraphic data from cores drilled at Mizuho
Station. Mem. Natl. Inst. Polar Res. Spec. Issue 10, 132-135. Naruse, R. 1979. Thinning of the ice sheet in Mizuho Plateau, East Antarctica. J. Glaciol., 24(90), 45-52.

Naruse, R. and H. Shimizu. 1978. Flow line of the ice sheet over Mizuho Plateau. Mem. Natl. Inst. Polar Res. Spec. Issue 7, 227-234.

National Institute of Polar Research. 1988. In Kawaguchi, S. and H. Kanzawa, eds, Science in Antarctica. 3. Meteorology. Tokyo, National Institute of Polar Research. [In Japanese.]

Nishio, F., ed. 1984. Glaciological research program in east Queen Maud Land, East Antarctica. Part 1, 1982-1983. Tokyo, National Institute of Polar Research. (JARE Data Reports 94 (Glaciology 10).)

Nishio, F., S. Mae, H. Ohmae, M. Nakawo, S. Takahashi, and K. Kawada. 1984. Dynamical behaviour of the ice sheet on Mizuho Plateau, East Antarctica. (Abstract.) Ann. Glaciol., 12, 205.

Oeschger, H., B. Stauffer, A. Neftel, J. Schwander, and R. Zumbrunn. 1982. Atmospheric $\mathrm{CO}_{2}$ content in the past deduced from ice-core analyses. Ann. Glaciol., 3, 227-232.

Raynaud, D. and B. Lebel. 1979. Total gas content and surface elevation of polar ice sheet. Nature, 281(5729), 289-291.

Raynaud, D. and I.M. Whillans. 1982. Air content of the Byrd core and past changes in the West Antarctic ice sheet. Ann. Glaciol., 3, 269-273.

Satow, K. and T. Kikuchi. In press. The $10 \mathrm{~m}$ snow temperature in the ice sheet. In Higashi, A. ed. Antarctica: East Queen Maud Land, Enderby Land; Glaciological Folio. Tokyo. National Institute of Polar Research.

Scholander, P.F., E.A. Hemmingsen, L.K. Coachman, and D.C. Nutt. 1961. Composition of gas bubbles in Greenland icebergs. J. Glaciol., 3(29), 813-822.

Schwander, J., B. Stauffer, and A. Sigg. 1988. Air mixing in firn and the age of the air at pore close-off. Ann. Glaciol., 10, 141-145.

Stauffer, B. and W. Berner. 1978. $\mathrm{CO}_{2}$ in natural ice. $J$. Glaciol., 21(85), 291-300.

Takahashi, S. and M. Nakawo. 1982. An estimation of the steady flow field along a flow line of Shirase Glacier, Antarctica. Seppyo, 44(4), 189-195. [In Japanese.] 